\title{
Singular case of acanthosis nigricans
}

\author{
Cristiana Maximiano (1) , ${ }^{1}$ Marta Ribeiro Silva, ${ }^{1}$ Maria Miguel Gomes, ${ }^{1}$ Ana Antunes ${ }^{1,2}$
}

'Paediatric, Hospital de Braga, Braga, Portugal

${ }^{2}$ Pediatric Endocrinology Unit, Hospital de Braga, Braga, Portugal

\section{Correspondence to}

Dr Cristiana Maximiano; cristiana.maximiano@gmail.com

Accepted 2 February 2021

\section{DESCRIPTION}

A 12-year-old Caucasian girl was referenced to a paediatric endocrinology consultation for extensive acanthosis nigricans (AN), hirsutism and severe obesity (Body Mass Index (BMI): $37.5 \mathrm{~kg} / \mathrm{m}^{2}$, z-score 3.57). She had a normal psychomotor development. Her mother and her maternal grandfather had obesity. Examination revealed Tanner 5 with deep voice, hirsutism (Ferriman and Gallwey score 14), abdominal and lumbar striae, and severe lesions of AN involving the neck, armpits, intermammary cleft and inframammary area (Burke score ${ }^{1} 11 / 14$ ) (figure 1). Biochemical evaluation revealed dyslipidaemia (triglycerides $213 \mathrm{mg} / \mathrm{dL}$ ), insulin resistance (IR) (insulin $43.5 \mu \mathrm{UI} / \mathrm{mL}$, HOMA-IR 10.2), high testosterone $(74 \mathrm{ng} / \mathrm{dL})$ and low sex hormonebinding globulin $(8 \mathrm{nmol} / \mathrm{L})$. She had menarche and there was no oligomenorrhea. Congenital adrenal hyperplasia and hypercortisolism were excluded. Oral glucose tolerance test was normal. In order to screen for a virilising tumour, an abdominal MRI was performed, showing regular adrenal glands but large ovaries (right ovary $27 \mathrm{~mm}$ and left ovary $29 \mathrm{~mm}$ ) with multiple millimetric cysts related to polycystic ovary syndrome (POS). Treatment comprised dietary and physical activity counselling, as well as a gradual treatment with metformin, pioglitazone, spironolactone and oral combined hormonal contraceptive. After 3 years of follow-up, although maintaining a BMI z-score of 3.57 , there was partial regression of AN (figure 2) and improvement in the biochemical evaluation: absence of dyslipidaemia and lower testosterone $(50.84 \mathrm{ng} / \mathrm{dL})$. IR has worsened (insulin $51.9 \mu \mathrm{UI} / \mathrm{mL}$, HOMA-IR 12.4), which may be due to the absence of weight loss and to pubertal physiological IR.

AN is characterised by dark and thickened skin, symmetrically distributed more frequently on the neck, axillae and groin folds. AN is usually associated with obesity, POS, type 2 diabetes, monogenic causes of IR and malignancy (particularly, gastric carcinoma, Wilm's tumour and virilising tumours). Paraneoplastic syndromes are often associated with severe $\mathrm{AN}^{2}$

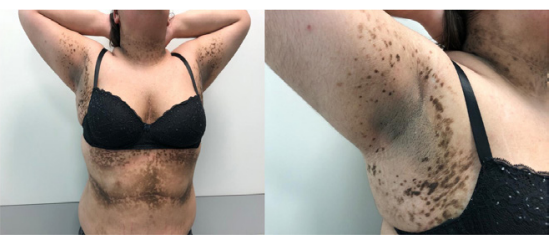

Figure 1 Severe acanthosis nigricans involving neck, armpits, intermammary cleft and inframammary area and abdominal striae; recorded at first consultation, aged 12 years.

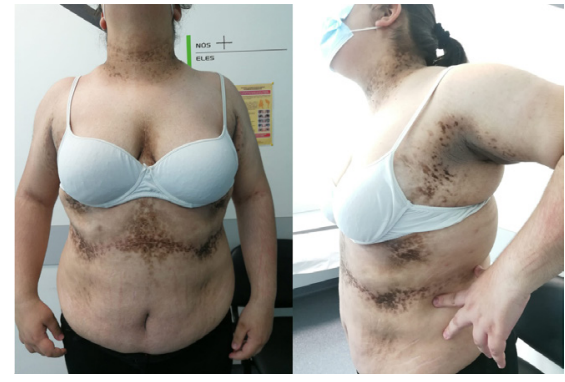

Figure 2 Lighter skin lesions of acanthosis nigricans especially on the neck, armpits and intermammary cleft; aged 15 years.

In AN related to obesity, increased insulin activates keratinocyte insulin-like growth factor (IGF) receptors, particularly IGF-1. At high concentrations, insulin may displace IGF-1 from IGF-binding proteins. Increased circulating IGF leads to keratinocyte and dermal fibroblast proliferation. Among patients with POS, AN is associated with higher free testosterone levels, which may be explained by the association with hyperinsulinaemia, which can promote ovarian thecal androgen secretion and inhibit hepatic synthesis of sex hormone-binding globulin, as in the case of our patient. ${ }^{3}$

AN is a manageable condition, however, the complete reversion of the lesions is difficult to achieve. Although weight reduction is acknowledged as the most efficient strategy to tackle AN, this report suggests that metformin and pioglitazone should be considered in order to improve insulin sensitivity and endocrine and metabolic indices, which may have a visible impact on AN extension. $^{34}$

In this case, despite the lack of hyperandrogenic signs (acne, alopecia or oligomenorrhea), it was imperative to exclude adrenal and abdominal malignancies. This report highlights a rare case of severe

\section{Learning points}

Severe acanthosis nigricans (AN) is rare and may be associated with malignancy or syndromic conditions.

- In case of patients with polycystic ovary syndrome (POS), AN is associated with higher free testosterone levels which are related to a hyperinsulinaemic state.

- Improvement of insulin sensitivity and free testosterone levels with metformin and pioglitazone may be determinant to manage AN in patients with POS. 
AN in which the aetiology was a non-malignant pathology: $\mathrm{C}$ phenotype POS.

Contributors CM conceptualised and wrote the article. MRS, MMG and AA offered guidance and suggestions, and edited the article. All authors participated in patient care and approved the final version of the article.

Funding The authors have not declared a specific grant for this research from any funding agency in the public, commercial or not-for-profit sectors.

Competing interests None declared.

Patient consent for publication Parental/guardian consent obtained.

Provenance and peer review Not commissioned; externally peer reviewed.
ORCID iD

Cristiana Maximiano http://orcid.org/0000-0001-9916-925X

\section{REFERENCES}

1 Videira-Silva A, Albuquerque C, Fonseca H. Acanthosis nigricans as a clinical marker of insulin resistance among overweight adolescents. Ann Pediatr Endocrinol Metab 2019;24:99-103.

2 Das A, Misra P, Panda S. Childhood acanthosis nigricans. Indian J Paediatr Dermatol 2019:20:199-204

3 Das A, Datta D, Kassir M. Acanthosis nigricans: a review. J Cosmet Dermatol 1865;2020:1857.

4 Trent M, Gordon CM. Diagnosis and management of polycystic ovary syndrome in adolescents. Pediatrics 2020;145:S210-8.

Copyright 2021 BMJ Publishing Group. All rights reserved. For permission to reuse any of this content visit

https://www.bmj.com/company/products-services/rights-and-licensing/permissions/

BMJ Case Report Fellows may re-use this article for personal use and teaching without any further permission.

Become a Fellow of BMJ Case Reports today and you can:

- Submit as many cases as you like

- Enjoy fast sympathetic peer review and rapid publication of accepted articles

- Access all the published articles

Re-use any of the published material for personal use and teaching without further permission

\section{Customer Service}

If you have any further queries about your subscription, please contact our customer services team on +44 (0) 2071111105 or via email at support@bmj.com.

Visit casereports.bmj.com for more articles like this and to become a Fellow 